\begin{tabular}{|c|c|c|}
\hline \multirow{3}{*}{$\begin{array}{r}\text { Case Reports in } \\
\text { Gastroenterology }\end{array}$} & \multirow{2}{*}{\multicolumn{2}{|c|}{ Case Rep Gastroenterol 2016;10:95-98 }} \\
\hline & & \\
\hline & $\begin{array}{l}\text { DOI: } 10.1159 / 000444443 \\
\text { Publisnea onine: nviay } 19,2016\end{array}$ & $\begin{array}{l}\text { (c) } 2016 \text { The Author(s) } \\
\text { Published by S. Karger AG, Basel } \\
\text { www.karger.com/crg }\end{array}$ \\
\hline & $\begin{array}{l}\text { This article is licensed under } \mathrm{t} \\
\text { International License (CC BY-N } \\
\text { Usage and distribution for comm }\end{array}$ & $\begin{array}{l}\text { mons Attribution-NonCommercial } 4.0 \\
\text { ger.com/Services/OpenAccessLicense). } \\
\text { uires written permission. }\end{array}$ \\
\hline
\end{tabular}

\title{
Idiopathic Adulthood Ductopenia: 'It Is Out There'
}

\author{
Mohammad Bilal Ali Kazemi Michael Babich \\ Division of Gastroenterology, Hepatology and Nutrition, Allegheny General Hospital, \\ Pittsburgh, Pa., USA
}

\section{Keywords}

Idiopathic adulthood ductopenia $\cdot$ Elevated alkaline phosphatase $\cdot$ Cholestasis

\begin{abstract}
Idiopathic adulthood ductopenia (IAD) is a chronic cholestatic entity of unknown origin characterized by loss of inter-lobular bile ducts that was first described two decades ago. Although the diagnostic criteria have been described in detail, IAD continues to be a rare diagnosis. Our thorough literature search revealed less than a hundred cases of IAD reported. Here we present a 34-year-old female with no significant past history who was evaluated for persistent elevation of serum alkaline phosphate levels. Serology was negative for all viral hepatitides, and a chronic liver disease workup was unremarkable. Magnetic resonance cholangiopancreatography and endoscopic retrograde cholangiopancreatography did not reveal any abnormalities in the biliary tree. Finally, a liver biopsy demonstrated ductopenia involving greater than $50 \%$ of the portal triads, making a diagnosis of IAD. Since the disease can progress rapidly, close follow-up is warranted, so liver transplantation can be pursued if deemed necessary.

(C) 2016 The Author(s)

Published by S. Karger AG, Basel
\end{abstract}




\section{Introduction}

Idiopathic adulthood ductopenia (IAD) is a rare chronic cholestatic entity of unknown origin characterized by loss of inter-lobular bile ducts that was first described over two decades ago [1]. Since its initial description, less than a hundred cases have been reported.

Abnormalities in liver function tests are routinely seen in clinical practice and at times are transient secondary to acute illnesses or drugs. Isolated elevation in serum alkaline phosphatase levels is often encountered and mostly occurs secondary to cholestasis. Since impairment of bile secretion can be at any point from the hepatocytes to the second part of the duodenum, the differential diagnosis for cholestatic disorders is usually broad. Primary biliary cirrhosis and primary sclerosing cholangitis are the most common causes of chronic cholestasis [2]. IAD is another cause of chronic cholestasis that involves the small bile ducts. Since the symptoms and presentation of IAD can be nonspecific, it continues to be a diagnosis of exclusion. To date, no specific test has been found to be solely related to IAD. Here we report an interesting case of IAD that was diagnosed after extensive workup.

\section{Case Report}

A 34-year-old female with a past medical history of cervical dysplasia was referred to our Hepatology Clinic by her primary care physician for persistent elevation of her serum alkaline phosphatase levels. On review of records, the patient was found to have the following laboratory values; total bilirubin, $0.4 \mathrm{mg} / \mathrm{dl}$ (normal: $0.2-1.2 \mathrm{mg} / \mathrm{dl}$ ), direct bilirubin, 0.2 $\mathrm{mg} / \mathrm{dl}$ (normal: 0.0-0.4 mg/dl), serum alanine transaminase, $32 \mathrm{IU} / \mathrm{l}$ (normal: 9-52 IU/l), serum aspartate transaminase, $23 \mathrm{IU} / \mathrm{l}$ (normal: 13-35 IU/l), serum alkaline phosphatase, $295 \mathrm{IU} / \mathrm{l}$ (normal: 38-126 IU/l), serum albumin, $4.4 \mathrm{~g} / \mathrm{dl}$ (normal: 3.5-5.0 g/dl), international normalized ratio, 1.0 (normal: 0.9-1.1). The patient's other laboratory abnormalities were only significant for elevation of serum gamma-glutamyl transpeptidase levels at $279 \mathrm{IU} / \mathrm{l}$ (normal: 12-58 IU/l). She did not have any symptoms. She was on no medications at home. Serology results for hepatitis A, B and C were negative. Results were also negative for antimitochondrial, anti-nuclear, anti-smooth muscle, anti-liver-kidney microsomal and antineutrophil cytoplasm antibodies. Serum alpha fetoprotein, alpha-1-antitrypsin, ceruloplasmin and ferritin levels were in the normal range. Magnetic resonance cholangiopancreatography was done which was normal. Endoscopic retrograde cholangiopancreatography was performed which showed diffuse pruning of the biliary tree with no dominant strictures or extra-hepatic biliary tree abnormalities. Finally, a liver biopsy was done which revealed ductopenia involving $60 \%$ of the portal triads, METAVIR stage II portal fibrosis and mild steatosis. No granulomas or florid bile duct lesions were appreciated. (fig. 1, fig. 2) The patient was diagnosed as having IAD based on the criteria defined by Ludwig. The patient was started on ursodiol $500 \mathrm{mg}$ three times a day and continues to be stable to date. She has been closely monitored over the past 3 years.

\section{Discussion}

IAD is a rare disorder which was first described by Ludwig and colleagues in 1988 [1]. Although the diagnostic criteria have been well described, the presentation of the disease is rare. The diagnostic criteria include the following. (i) The patient must be an adult or at least 
Bilal et al.: Idiopathic Adulthood Ductopenia: 'It Is Out There'

an adolescent. (ii) Biochemical evidence of cholestatic liver disease and biopsy evidence of ductopenia. (iii) Biopsy should show a decrease in intrahepatic bile ducts in at least $50 \%$ of the portal tracts. (iv) No identifiable cause of cholestasis should be present [3]. It is important for medical practitioners to be aware of IAD because it has a very benign presentation and can be easily missed or neglected. The progression of this entity also varies from a benign course to serious outcomes $[4,5]$. Ursodiol has been used in some case studies with symptomatic relief [5, 6]. The only definitive treatment is orthotopic liver transplantation [3, 7]. Since the disease can progress rapidly, it is important for physicians to closely monitor these patients, and liver transplantation can be pursued timely if deemed necessary.

This case highlights the fact that IAD may be more common than previously thought. The subtle presentation and rarity of this disease can make the diagnosis challenging. IAD should be considered in the differential diagnosis of persistent elevation of alkaline phosphatase levels, so that early referral to a dedicated hepatology center could be made to follow progression of disease.

\section{Statement of Ethics}

The published research is compliant with the guidelines for human studies and animal welfare regulations.

\section{Disclosure Statement}

The authors report no conflict of interest and no financial declaration.

\section{References}

1 Ludwig J, Wiesner RH, LaRusso NF: Idiopathic adulthood ductopenia. A cause of chronic cholestatic liver disease and biliary cirrhosis. J Hepatol 1988;7:193-199.

-2 Kim WR, Ludwig J, Lindor KD: Variant forms of cholestatic diseases involving small bile ducts in adults. Am J Gastroenterol 2000;95:1130-1138.

3 Ludwig J: Idiopathic adulthood ductopenia: an update. Mayo Clin Proc 1998;73:285-291.

4 Dominguez-Antonaya M, et al: Idiopathic adulthood ductopenia: a diagnosis: two clinicopathologic courses. J Clin Gastroenterol 2000;30:210-212.

5 Moreno A, et al: Idiopathic biliary ductopenia in adults without symptoms of liver disease. N Engl J Med 1997;336:835-838.

-6 Hartmann H, Grone HJ: Idiopathic ductopenia of adulthood: favorable effect of ursodeoxycholic acid therapy (in German). Z Gastroenterol 1993;31(suppl 2):131-133.

7 Kaung A, et al: A case of mild idiopathic adulthood ductopenia and brief review of literature. Gastroenterol Rep (Oxf) 2015;3:167-169. 


\section{Case Reports in \\ Case Rep Gastroenterol 2016;10:95-98 \\ Gastroenterology \\ (C) 2016 The Author(s). Published by S. Karger AG, Basel www.karger.com/crg \\ Bilal et al.: Idiopathic Adulthood Ductopenia: 'It Is Out There'}

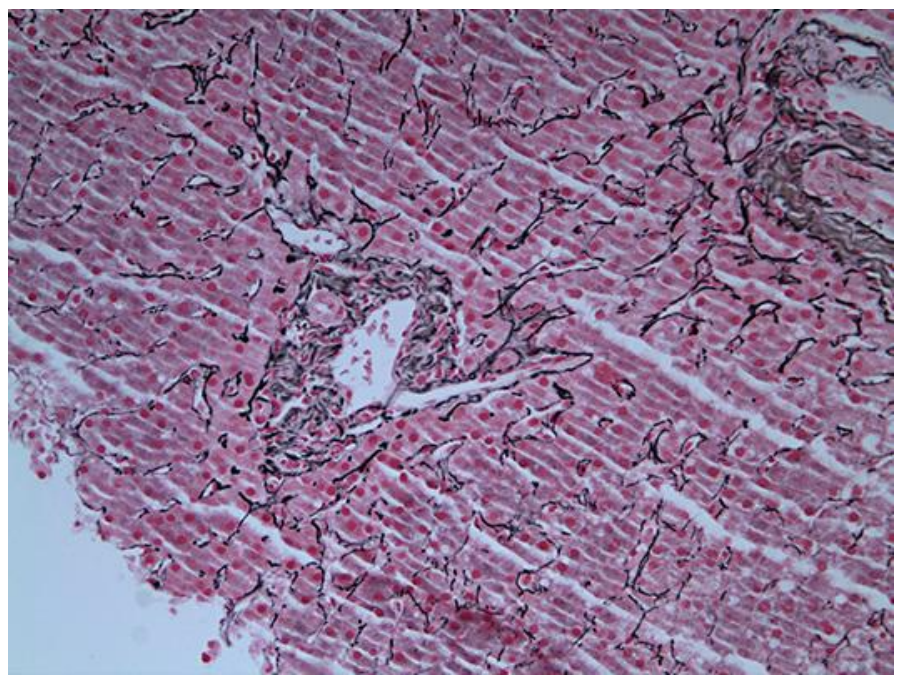

Fig. 1. Low-power magnification: portal tract showing absence of bile duct and ductular proliferation. Reticulin stain.

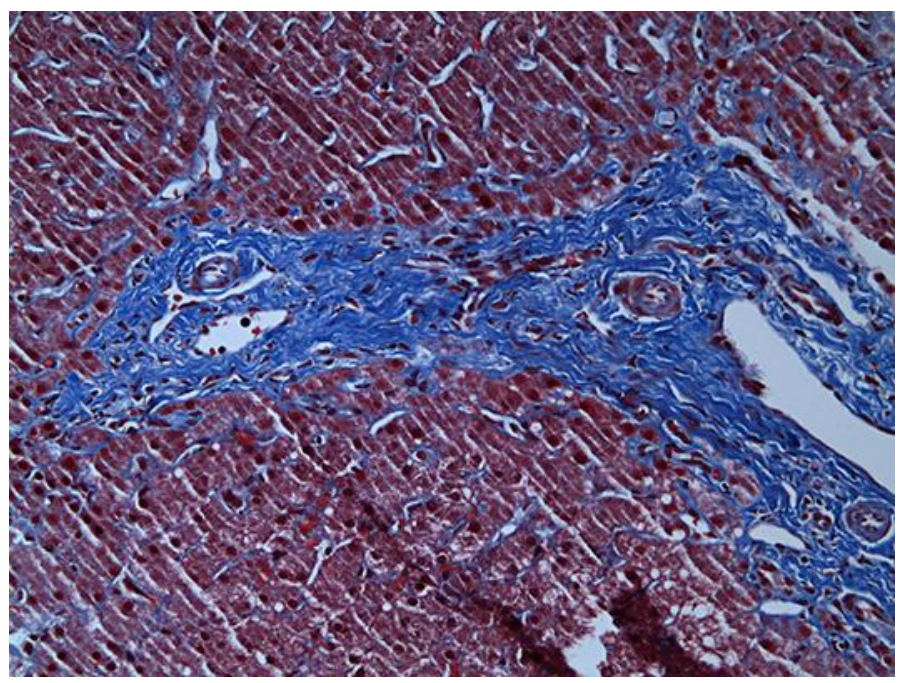

Fig. 2. High-power magnification: portal tract showing portal fibrosis and intrasinusoidal fibrosis. Masson's trichrome stain. 